\title{
Effects of Spraying Irradiated Alginate on Solanum tuberosum L. Plants: Growth, Yield and Physiological Changes of Stored Tubers
}

\author{
Omaima Sayed Hussein*, NAHLA Hamideldin \\ National Products Research Department, National Center for Radiation Research and Technology, P. O. Box; \\ 29 Nasr City, Egypt
}

\begin{abstract}
The effect of depolymerized form of sodium alginate, produced by irradiating it by ${ }^{60}$ Co gamma rays, studied on two varieties of Solanum tuberosum L. (Bern and Kara) with regard to growth attribute, physiological and biochemical parameters. The study revealed that the irradiated sodium alginate (ISA) applied as foliar sprays with concentration $0.3 \%$ had a stimulatory effect on specific morphological parameters and led to increase in plant yield significantly. The total soluble solids (TSS) in treated samples of Bern and Kara varieties before and after storage slightly increase but not reached the level of significance except in Bern variety that remain stable after storage. Significant changes in total phenol concentrations before and after storagecomparing with untreated control samples, except Kara before storage.In addition, there is a significant change in starch content. The changes in elements concentration of potato tubers that produced from plants sprayed by ISA solution indicate that calcium, chlorine, ferrous and magnesium too declined to undetect in magnesium element of Bern variety. Nevertheless, in variety Kara sodium element instead of ferrous decreased. However, potassium, magnesium and phosphorus were increased.
\end{abstract}

Keywords: Solanum tuberosum, irradiated sodium alginate, growth, yield, starch, phenol

\section{INTRODUCTION}

Potato (Solanum tuberosum L.) is one of the unique and potential crops having high productivity, supplementing major food requirement in the world. It is rich in carbohydrates, proteins, phosphorus, calcium, vitamin $\mathrm{C}$, carotenes and has a high protein calorie ratio. The ratio of protein to carbohydrate is higher in potato than in many cereals and other tuber crops (Marwaha, 1999). It constitutes nearly half of the worlds annual output of all root and tuber crops and has always remained in the top ten since last twenty years. Among minor chemical constituents, represent a large group in potato phenol compounds, which play an important role in determining their organoleptic properties and consider one of a health promoting phytonutrients. The phenol content of potatoes was high and ranged from 530 to $1770 \mu \mathrm{g} \mathrm{g}^{-1}$ (Al-Saikhan, et al., 1995). It was the third most important source of phenols after apples and oranges (Chun et al., 2005). There is a worldwide trend to explore new natural products acts as growth promoters for plants and control postharvest pathogenic diseases and side effects on human because of agrochemicals application.

Among high molecular polymer, nontoxic, bioactive agent derived from animal or plants sodium alginate (SA), chitosan or carageenan, they are degradable natural products which become a useful appreciated compound due to its biofertilizer, fungicidal effects or elicitation of defense mechanisms in plants tissues, (Aftab et al., 2011 ; Hu et al., 2004; Khan et al., 2010;Abd El-Rehim et al., 2011). Previous studies show that alginate coatings prolong storage-life and control decay of table grape (Ramanazzi et al., 2002) and strawberry (El Ghaouth et al., 1991). Abd El-Rehim et al. (2011) added that combining both gamma irradiation and oxidizing agents accelerated degradation rate and dramatically decreases sodium alginate molecular weight. They added that their degradation in solution was remarkably greater than that in solid and required one/tenth the dose used in degradation of solid alginate. The, objective of this research was to investigate the influence of foliar spray with irradiated sodium alginate (ISA) solution on physiological changes of potato (Solanum tuberosum L.) plants, tuber produced and their storage at room temperature.

\section{Materials And Methods}

Two varieties of potato tubers named Bern and Kara obtained from the Agriculture Research Center, Giza, Egypt. The Tubers planted at the farm, of National Centre for Radiation Research and Technology (NCRRT), Cairo, Egypt in sandy- loam soil. Plants fertilized according to the recommendations of the Egyptian Ministry of Agriculture and Reclamation (150 kg calcium super phosphate /fed, $100 \mathrm{~kg}$ potassium sulphate /fed and $100 \mathrm{~kg}$ ammonium sulphate/fed). Sodium alginate (SA) solution of high molecular weight irradiated by 25 kGy gamma rays using ${ }^{60} \mathrm{Co}$ as source of radiation at NCRRT. Gamma radiation $(25 \mathrm{kGy})$ in combining with $2 \%$ silver nanoparticles accelerated the degradation rate of SA MW $3.2 \times 10^{4}$. The degradation in solution was remarkably greater than that in solid and required one/tenth the dose used in degradation of solid alginate. 
Potato seedlings sprayed by ISA solution that applied as sprays at a concentration of $0.3 \%$ monthly until harvest date.

\section{A. Growth parameters}

Shoot length $\left(\mathrm{cm}^{-1}\right)$, number of stems and number of leaves (plant $\left.{ }^{-1}\right)$, stem and leaf area and tuber diameter before and after storage $\left(\mathrm{cm}^{-2}\right)$, tuber weight before and after storage $\left(\mathrm{g}^{-1}\right)$. The tubers produced were stored for 90 days in ambient air and the changes in their physicochemical properties before and after storage were estimated.

\section{B. Physical properties}

The physical properties determined were moisture content, firmness, total soluble solids (TSS), and specific gravity. Moisture content of tubers was determined according to (AOAC, 1975).Firmness measured on instrument present in NCRRT, the pounds of pressure required to force a plunger 5/16 of an inch in diameter into potato to a depth of 5/16 inches. Tests made at approximately the same position on each tuber. The total soluble solids (TSS) were determined in a drop of potato juice using Abbé refractometer according to (AOAC, 1990). Specific gravity (SG) measurements, after cleaning the samples with tap water done, tubers suspended from a load cell and measure the weight in air and under water (Anonymous, 1999).The SG calculated according to equation: Specific gravity= weight in air/ (weight in air-weight in water).

C. Chemical properties: The chemical properties determined were total phenols, starch and minerals ratios.

C.1. Total phenols: The total phenols content estimated in the acetone, methanol and water extracts of irradiated and control samples of the plant using the method described by (Malik and Singh.1980).In a test tube, an aliquot of the extract made up to a final volume of $7 \mathrm{~mL}$ with distilled water and shake. $0.5 \mathrm{~mL}$ of folinphenol reagent added; shake vigorously and after 3 minutes $1 \mathrm{~mL}$ of $35 \%$ sodium, carbonate solution added. After shaking, it kept for $1 \mathrm{~h}$ and the absorbance of the green-blue complex formed measured at $630 \mathrm{~nm}$ against blank control. The blank made from all reagents minus folin reagent. The values of unknowns calculated from calibration curve made from different concentrations of gallic acid. Results expressed as gallic acid equivalents $\mathrm{mg} \mathrm{g}^{-1}$ of dry weight of the extracts.

C.2. Estimation of Starch: starch estimated by anthrone reagent method according to (Hodge et al., 1962) as modified by (Thayumanavan and Sadasivam 1984). The samples extracted with $80 \%$ ethanol solution to remove sugars, then starch hydrolyzed to glucose with $52 \%$ perchloric acid. Pipettes $1 \mathrm{~mL}$ of the diluted solution into glass tubes, cool and add $4 \mathrm{~mL}$ of freshly prepared anthrone reagent to all of samples. Tubes cooled, mix thoroughly and heat for 8 minutes in a boiling water bath. The tubes cooled rapidly in water bath and the color intensities measured at wavelengths 630-nm.All spectrophotometric work performed using Shimadzu 120-02 UV/Visible spectrophotometer. Starch in samples was estimated from a standard calibration curve of starch solution contain $20-100 \mu \mathrm{g}$.

C.3. Minerals: minerals measured at NCRRT on Energy Dispersive X-Ray-Analysis Model: (Oxford) attached to a scanning electron microscope (JEOL-JSM 5400). Analysis depends on X-ray radiation emitted from each element. When the specimen bombarded with high energetic electrons- utilized to determine the kind of the elements that exists in the specimen surface and their percentage. The elements estimated were calcium, chlorine, potassium, magnesium, sodium and phosphorus.

Statistical Analysis: the Data obtained analyzed statistically using Costat statistical program software, 1990 and Duncan's multiple range test (Duncan, 1955) applied at 5\% probability level to compare the differences among means.

\section{Results And Discussion}

The different vegetative growth parameters recorded during the experiment were plant height, number of stems and number of leaves plant ${ }^{-1}$. It was observed that the maximum height of plants $(51.2 \mathrm{~cm})$ obtained with untreated control Kara followed by plants treated by $0.3 \%$ alginate. The reverse occurred in variety Bern, where, the maximum height of plant $(49.0 \mathrm{~cm})$ obtained with $0.3 \%$ alginate followed by untreated plant. It was noticed that treated plants showed higher number of leaves (12.6) in Bern variety followed by (17.6) in variety Kara. The results obtained were in accordance with (Nolte et al., 2003) who found similar results in Russet Burbank potatoes. Similarly, Abd El-Rehim et al 2011 shows that the treatment of Zea mays plants with the 120, 160, and $200 \mathrm{kGy}$ ISA not only enhances the plant growth performance but also increases its productivity. Khan et al. (2010) also confirmed the growth promoting effect of ISA in Papaver somniferum. IAEA-RCA reported that after the cucumber sprayed three times with alginate solution, the seedling quality and major characters of cucumber were better than the blank group, their yield also increased by 15 to $20 \%$. In response to the effect of the treatment with ISA on the number of stems/ plant, stems diameter and tuber size after storage, insignificant 
change observed, and showed significant difference higher than control in the size of tuber before storage and in its weight before and after storage (Table1).

Table 1.Changes in vegetative growth and yield parameter of two potato varieties Bern and Kara sprayed by ISA.

\begin{tabular}{|c|c|c|c|c|c|c|c|c|c|c|}
\hline Varieties & Treatment & $\begin{array}{l}\text { Plant } \\
\text { height } \\
(\mathrm{cm})\end{array}$ & $\begin{array}{l}\text { Leaf } \\
\text { number }\end{array}$ & $\begin{array}{l}\text { Leaf } \\
\text { area } \\
\left(\mathrm{cm}^{2}\right)\end{array}$ & $\begin{array}{l}\text { Stem } \\
\text { number. }\end{array}$ & $\begin{array}{l}\text { Stem } \\
\text { diameter } \\
(\mathrm{cm})\end{array}$ & $\begin{array}{l}\text { Tuber } \\
\text { diameter } \\
\text { before } \\
\text { storage } \\
(\mathrm{cm})\end{array}$ & $\begin{array}{l}\text { Tuber } \\
\text { diameter } \\
\text { After } \\
\text { storage } \\
(\mathrm{cm})\end{array}$ & $\begin{array}{l}\text { Tuber } \\
\text { Weigh } \\
\text { before } \\
\text { storage } \\
(\mathrm{g})\end{array}$ & $\begin{array}{l}\text { Tuber } \\
\text { weight } \\
\text { after } \\
\text { storage } \\
\text { (g) }\end{array}$ \\
\hline \multirow{2}{*}{ Bern } & Control & $43.0 \mathrm{a}$ & $11.6 \mathrm{c}$ & $17.59 \mathrm{ab}$ & $17.8 \mathrm{~b}$ & $0.84 \mathrm{a}$ & $35.52 \mathrm{~b}$ & $31.56 \mathrm{a}$ & $247.7 \mathrm{~d}$ & $219.92 \mathrm{c}$ \\
\hline & $0.3 \%$ & $49.0 \mathrm{a}$ & $12.6 b c$ & $17.10 \mathrm{ab}$ & $22.0 \mathrm{a}$ & $0.90 \mathrm{a}$ & $44.56 \mathrm{a}$ & $32.52 \mathrm{a}$ & $498.6 b$ & $387.4 b$ \\
\hline \multirow{2}{*}{ Kara } & Control. & $51.2 \mathrm{a}$ & $17.6 \mathrm{a}$ & $20.67 a$ & $15.0 \mathrm{~b}$ & $0.76 \mathrm{a}$ & $34.01 \mathrm{~b}$ & $32.7 \mathrm{a}$ & $308.0 \mathrm{c}$ & $262.2 \mathrm{c}$ \\
\hline & $0.3 \%$ & $46.4 \mathrm{a}$ & $16.4 \mathrm{ab}$ & $14.4 \mathrm{~b}$ & $17.0 \mathrm{~b}$ & $0.78 \mathrm{a}$ & $43.73 \mathrm{a}$ & $33.98 \mathrm{a}$ & $601.0 \mathrm{a}$ & $476.9 \mathrm{a}$ \\
\hline
\end{tabular}

Each value is the mean of ten replicates, different letters indicate significant variation

ISA had a stimulatory effect on specific morphological parameters and led to increase in plant yield. Similar finding obtained by(Aftab et al.,2011) who revealed that ISA at 20-120 ppm concentration improved the plant growth; they ascribed the enhancement of ISA to $\mathrm{H}_{2}, \mathrm{O}_{2}$ in leaves. Hien et al. (2000) informed that application of depolymerized SA resulted in a significant enhancement of net photosynthesis and $\mathrm{CO}_{2}$ assimilation in rice. John et al. (1997) attributed the important role of SA led to stimulation of various physiological processes to inducing cell signaling in plants. In addition, (Kume et al., 2002; Khan et al., 2010) confirmed the growth promoting effect of ISA. The storage losses of potatoes often specified as weight and quality losses, as in untreated samples, and caused mainly by respiration, sprouting, spread of diseases, dehydration, changes in chemical composition of the tuber or damage by extreme temperature (Brook et al.1995; Graee and Aarseth 1993; Meijers et al. 1987; Rastovesk 1987). Compared with untreated control samples showed significant loss in moisture content after storage it was $25.93,12.26 \%$ in Bern and 2.15, 3.06\% in Kara, untreated and treated variety, respectively (Table 2).The mass percent decreased as sucrose concentration increased, therefore, relative osmotic concentration also decreased. Firmness estimated after storage and noticed that it correlated with moisture loss after of storage. The water content of fresh weigh potatoes varies for a number of reasons, variety being one. Values reported in literature for moisture content of fresh weight potato, raw, range from $63-87 \%$ (Chtterjee et al., 2006). It is likely that some of the differences in nutrients composition related to the differences in water contents. Firmness increase with increase in moisture loss of potatoes tubers. Before storage, slight increases in TSS of samples treated by ISA in the two varieties studied but not reach the level of significance and remain stable in Kara variety after storage.

Table2. Changes in physical properties of two potato varieties Bern and Kara sprayed by ISA

\begin{tabular}{|c|c|c|c|c|c|c|c|c|}
\hline Varieties & Treatment & $\begin{array}{c}\text { Moisture } \\
\% \\
\text { before } \\
\text { storage } \\
\end{array}$ & $\begin{array}{c}\text { Moisture } \\
\% \\
\text { after } \\
\text { storage } \\
\end{array}$ & $\begin{array}{c}\text { firmness } \\
\text { after } \\
\text { storage }\end{array}$ & $\begin{array}{l}\text { TSS } \\
\text { before } \\
\text { storage }\end{array}$ & $\begin{array}{c}\text { TSS } \\
\text { after } \\
\text { storage }\end{array}$ & $\begin{array}{c}\text { Specific } \\
\text { gravity } \\
\text { before } \\
\text { storage }\end{array}$ & $\begin{array}{c}\text { Specific } \\
\text { gravity } \\
\text { after } \\
\text { storage }\end{array}$ \\
\hline \multirow{2}{*}{ Bern } & Control & $83.333^{\mathrm{a}}$ & $61.72^{b}$ & $2.93^{\mathrm{a}}$ & $6.50^{\mathrm{a}}$ & $7.38^{\mathrm{a}}$ & $1.026^{\mathrm{b}}$ & $1.016^{\mathrm{ab}}$ \\
\hline & $0.3 \%$ & $82.99^{\mathrm{a}}$ & $72.81^{\mathrm{ab}}$ & $2.56^{\mathrm{a}}$ & $7.13^{\mathrm{a}}$ & $7.38^{\mathrm{a}}$ & $1.073^{\mathrm{b}}$ & $1.02^{\mathrm{ab}}$ \\
\hline \multirow{2}{*}{ Kara } & Control & $78.76^{\mathrm{b}}$ & $77.07^{\mathrm{a}}$ & $2.88^{\mathrm{a}}$ & $6.82^{\mathrm{a}}$ & $7.19^{\mathrm{a}}$ & $1.186^{\mathrm{a}}$ & $1.033^{\mathrm{a}}$ \\
\hline & $0.3 \%$ & $76.76^{\mathrm{b}}$ & $74.48^{\mathrm{a}}$ & $2.99^{\mathrm{a}}$ & $8.00^{\mathrm{a}}$ & $7.75^{\mathrm{a}}$ & $1.100^{\mathrm{ab}}$ & $1.013^{\mathrm{b}}$ \\
\hline
\end{tabular}

Regarding to SG in variety Bern not reach to the level of significance before and after storage, while in variety Kara significant change was observed due to the treatment used as compared by untreated control. Insignificant change in SG after storage between variety and treatment was according (ASAE STANDERS, 1998). Smith (1977) mentioned that the high specific gravity of potatoes is preferred for potato chips, while the low gravity tubers are preferred for canning.

The chemical characters results of phenol content, starch content and mineral ratio illustrated in (Table 3).Insignificant changes in the mean of two varieties under study in total phenol concentrations before and after storage but significant changes after storage observed in Kara where increased by $0.88 \%$ above control one. The phenol content of potatoes was high and ranged from 530 to $1770 \mu \mathrm{g} / \mathrm{g}$ (Al-Saikhan, et al., 1995). In unpeeled, undamaged or uncut potatoes, the browning does not occur because natural phenol substrates separated from the enzyme that responsible for browning. Phenolic compounds play an important role in determining potatoes organoleptic properties (Bravo, 1998). He added that phenolics have wide-array of health providing 
characteristics therefore have potential for use as functional food for improving human health. The same trends observed by (Ezekiel et al., 2008; Blessington et al., 2010) no significant differences in total phenol content of potatoes of two varieties grown at three locations in the North Indian plains having similar altitude but varying in temperatures during crop growth or when stored potatoes at 4 or $20{ }^{\circ} \mathrm{C}$ for 110 days. Spraying plants by $300 \mathrm{mg} \mathrm{mL}^{-1}$ ISA increase starch in potato tuber produced. In Bern, variety starch increased $12 \%$ while in Kara increased $31 \%$ as compared by its corresponding control. While, there are a little variation in starch content between the two varieties after storage for 90 days, but starch content decrease from 7-17\% as compared by unstored tuber. The decrease in starch content of potato after storage period for 90 days was due to catabolic reaction and the utilization of starch during respiration. Walter et al. (1992) reported that the sweet potato cultivars have active and B-amylase system, which have $\mathrm{pH}$ optimum near 6 . Consequently, shifting the $\mathrm{pH}$ away from this value would result in less than optimal enzymatic activity.

Table3. Changes in total phenol and starch content $\left(\mathrm{mg} \mathrm{g}^{-1}\right)$ of two potato varieties Bern and Kara sprayed by ISA

\begin{tabular}{cccccc}
\hline Varieties & Treatment & $\begin{array}{c}\text { Phenol } \\
\text { before } \\
\text { storage }\end{array}$ & $\begin{array}{c}\text { Phenol } \\
\text { after } \\
\text { storage }\end{array}$ & $\begin{array}{c}\text { Starch } \\
\text { Before } \\
\text { Storage }\end{array}$ & $\begin{array}{c}\text { Starch } \\
\text { after } \\
\text { storage }\end{array}$ \\
\hline Bern & Control & $0.569 \mathrm{a}$ & $0.572 \mathrm{ab}$ & $6.03 \mathrm{c}$ & $5.61 \mathrm{~b}$ \\
& $0.3 \%$ & $0.565 \mathrm{c}$ & $0.573 \mathrm{ab}$ & $5.62 \mathrm{~b}$ & $5.78 \mathrm{~b}$ \\
Kara & Control & $0.566 \mathrm{~b}$ & $0.571 \mathrm{~b}$ & $0.576 \mathrm{a}$ & $5.22 \mathrm{a}$ \\
\hline
\end{tabular}

Each value is the mean of ten replicates, different letters Indicate significant variation.

The changes in minerals of potato tubers that produced from plants sprayed by ISA solution indicate that calcium, chlorine, ferrous and magnesium too declined to undetect as in magnesium of Bern variety as shown in table 4. Nevertheless, in variety Kara sodium instead of ferrous decreased and potassium, magnesium and phosphorus increased. Minerals variation in tubers produced from plant sprayed by ISA, represent one of the important constituents of potato tubers.

Table 4. Change in minerals ratio of two potato varieties Bern and Kara sprayed by ISA.

\begin{tabular}{|c|c|c|c|c|c|c|c|c|}
\hline Varieties & Treatment & $\mathrm{Ca}$ & $\mathrm{Cl}$ & $\mathrm{Fe}$ & $\mathrm{K}$ & $\mathrm{Mg}$ & $\mathrm{Na}$ & $\mathrm{P}$ \\
\hline & Control & $12.96 \mathrm{a}$ & $11.6 \mathrm{~b}$ & $1.48 b$ & $52.87 \mathrm{c}$ & $9.64 a$ & $7.73 \mathrm{c}$ & $3.72 b c$ \\
\hline Bern & $0.3 \%$ & $5.47 \mathrm{c}$ & $7.07 \mathrm{c}$ & $1.20 \mathrm{bc}$ & $67.8 \mathrm{a}$ & - & $16.0 \mathrm{a}$ & $4.87 \mathrm{a}$ \\
\hline \multirow{2}{*}{ Kara } & Control & $8.82 b$ & $17.21 \mathrm{a}$ & $0.87 \mathrm{c}$ & $53.08 \mathrm{c}$ & $8.55 \mathrm{c}$ & $8.38 b$ & $3.11 \mathrm{c}$ \\
\hline & $0.3 \%$ & $1.33 \mathrm{~d}$ & $11.21 \mathrm{~b}$ & $2.21 \mathrm{a}$ & $66.1 \mathrm{~b}$ & $8.86 b$ & $6.21 \mathrm{~d}$ & $4.07 b$ \\
\hline
\end{tabular}

Each value is the mean of three replicates, different letters Indicate significant variation

\section{IV.CONCLUSION}

The application of irradiated sodium alginate solution, as foliar spray, has achieved good results. It has improved the growth attributes and enhanced the metabolic activities. Sodium alginate has made a major contribution to the quality and measurements of the produced tuber. Considering the high demand and consumption of tuber all over the world, applying sodium alginate on large scale is recommended.

Acknowledgment

Authors thank Professor Dr. Hassan Abd El-Rehim professor in chemistry department, NCRRT for preparing and providing ISA.

\section{REFERENCES}

[1] A.O.A.C.(1975).Official Methods of Analysis of the Association of official Analytical Chemists, Arlington Virginia, Washington, DC., USA. 
[2] A.O.A.C. (1990). Official Methods of Analysis. Association of of official Analytical Chemist (15 ${ }^{\text {th }}$ ed), AOAC, Washington, DC, USA.

[3] Anonymous,1999.VO2718/1999. Official journal of the European Union42L327/37(21.12.1999).

[4] Abd El-Rehim, H. A., El-Sawy, N. M., Farag, I. A., Elbarbary, A. A. Synergistic effect of combining ionizing radiation and oxidizing agents on controlling degradation of Na-alginate for enhancing growth performance and increasing productivity of Zea maize plants. Carbohydrate Polymers. 86 (2011) 1439-1444.

[5] Aftab, T., Khan, M. M. A., Idrees, M., Naeem, M., Moinuddin, Hashmi, N. and Varshney, L Enhancing the growth, photosynthetic capacity and artemisinin content in Artemisia annua L. by irradiated sodium alginate. Rad. Phys and Chem. 80 (. 2011 ) 833-836.

[6] Al-Saikhan, M. S., Howard, L. R. and Miller, Jr. J. C. Antioxidant activity and total phenolics in different genotypes of potato (Solanium tuberosum L.) J. food Sci. 60 (1995) 341-343.

[7] ASAE standards 1998. Loads exerted by Irish potatoes in shallow bulk storage structures. ANSI/ASAE EP 446.2 DEC 95.Baritelle (1997).

[8] Blessington, T., Nzaramba, M. N., Scheuring, D. C., Hale, A. L., Reddivari, L., \& Miller, J. C., Jr. Cooking methods and storage treatments of potato: Effects on carotenoids, antioxidant activity, and phenolics. American Journal of Potato Research, 87 (2010) 479-491.

[9] Bravo, L.Polyphenols: Chemistry, dietary sources, metabolism and nutritional significance Nutrition Reviews, 56 (1998) $317-333$.

[10] Brook, R. C., Fick, R. J. and Forbush, T. D. Potato storage design and management. Am. Potato J 72 (1995)463-480.

[11] Chtterjee, C., Gopal, R, Dube, B.K. Impact of iron stress on biomass, yield, metabolism and quality of potato (Solanium tuberosum L.) Scientia Horticulturae108 (2006) 1-6.

[12] Chun, O. K., Kim, D. O., Smith, N., Schroeder, D., Han, J.T. and Lee, C.y. Daily consumption of phenolics and total antioxidant capacity from fruit and vegetables in the American diet. J Sci Food Agric85 (2005)1715-1724.

[13] Duncan, D. B.multiple ranges and multiple F. test. Biometrics. 11(1955) 1.

[14] El Ghaouth, A., Arul, J., Ponnampalam, R. and Boulet, M. Alginate coating effect on storability and quality of fresh strawberries. $J$ Food Sci 56(1991)1618-1620.

[15] Ezekiel, R., Singh, B., Kumar, D., \& Kumar, A. Effect of growing location on the processing quality of two potato cultivars stored at low temperature. Indian Journal of Horticulture, 65 (2008) 52-59.

[16] Graee, T. and Aarseth, L. I. Universal stores for fresh plant products (1993). Melding Inst. Tekniske-Fag Norges Land brukshogs kole. 20-21, 28 pp. (in Norwegian).

[17] Kleinkopf, G.E. Early season storage. Am. Potato J 72 (1995) 449-462.

[18] Hien, N. Q., Nagasawa, N., Tham, L. X., Yoshii, F., Dang, H. V., Mitomo, H., MakuuchiK and Kume, T. Growth promotion of plants with depolymerised alginates by irradiation. Radiation Physics and Chemistry 59 (2000) 97-101.

[19] Hodge, J. E. and Hofreiter, B. T. In: Methods in Carbohydrate Chemistry (1962) (eds Whistler, R L and Be Miller, J N) Academic Press New York.

[20] Hu, p., Jiang, X., Hwang, H., Liu, S. and Guan, H. Promotive effects of alginate-derived oligosaccharide on maize seed $I$ oak germination. J Applied Physiol 6 (2004) 73-76.

[21] Jiménez, M.E., Rossi, A.M. and Sammán, N. C.Phenotypic, agronomic, nutritional characteristics of seven varieties of Andean potatoes. Journal of Food Composition and Analysis 22 (2009) 613-616.

[22] John, M., Schmidt, J., Walden, R. and Schell, J.Cell signaling by oligosaccharides. Trends Plant Sci 3 (1997) 111-115.

[23] Khan, Z. H., Khan, M. MA., Aftab, T. Idrees, M., and Naeem, M.Influence of alginate oligosaccharides on growth, yield and alkaloid production of opium poppy (Papaver somniferum L.). Front. Agric. China 5 (2010) 122-127.

[24] Kume. T., Nagasawa, N. and Yoshii. F. Utilization of carbohydrates by radiation processing. Radiation Physics and Chemistry 63 (2002) 625-627.

[25] Marwaha, R. S.Chipping quality and related processing characteristics of Indian potato varieties grown under short day conditions. J. Food Sci Techno36 (1999) 157-159

[26] Malik, C.P.and Singh, M.B. A text manual" plant enzymology and histoenzymology (1980). Kalyani publishers, Ludhiara

[27] Meijers, S., Mabrouk, Y., Vision, M., Delavault, P., Simier, P., Saidi, M. and Belhadj, O. Variation in quantitative characters of faba bean after seed irradiation and associated molecular changes. African journal of biotechnology 11 (1987) 8383-8390.

[28] Negi, P. S. and Nath, N. Effect of partial dehydration on quality of canned potatoes. Eur. Food Res. and Tech. 215 (2002) .231-234.

[29] Nolte, P., Bertram, M., Bateman and Mcintosh, C. I..Comparative effects of cut and treated seed tubers verses untreated whole seed tubers on seed decay, Rhizoctonia stem canker, Growth and yield of Russet Burbank potatoes. Am. J Potato Res 80 (2003) 1-8.

[30] Ramanazzi, G., Nigro, F., Ippolito, A., Di Venere, D. and Salerno, M. Effects of pre and post harvest treatments to control storage grey mold of table grapes. J Food Sci67 (2002)1862-1867.

[31] Rastovesk, A. Storage losses. In: Rastovesk, A and A Van Es (eds.). Storage of potatoes: Post-harvest behavior, store design, storage practice, handling (1987). Wageningen, The Netherlands: Pudoc. 177-180.

[32] Smith, O. Potatoes; production, storing, processing (1977). The AVI pub. Co., INC. Westport, Connecticut.

[33] Thayumanavan, B. and Sadasivam, S. Qual Plant Foods Hum Nut34 (1984) 253.

[34] Walter, W. M. J r, Fleming, H. P. and Mc Feeters, R. F.Firmness control of sweet potato French fry- type product by tissue acidification. J Food Sci. (57(1992) 138-142. 